\title{
Investigating the Facebook Applications and Their Impact on Customer Loyalty in the Turkish Mobile Telecommunication Industry
}

\author{
Fatih Geçti ${ }^{1} \&$ Niyazi Gümüş ${ }^{2}$ \\ ${ }^{1}$ Faculty of Economics and Administrative Sciences, Yalova University, Turkey \\ ${ }^{2}$ Faculty of Economics and Administrative Sciences, Kastamonu University, Turkey \\ Correspondence: Fatih Geçti, Department of Management, Faculty of Economics and Administrative Sciences, \\ Yalova University, Safran Campus, 77100, Yalova, Turkey. E-mail: fgecti@yalova.edu.tr
}

Received: March 27, 2014

Accepted: April 25, 2014

Online Published: April 28, 2014

doi:10.5539/ijbm.v9n5p195

URL: http://dx.doi.org/10.5539/ijbm.v9n5p195

\begin{abstract}
The competition in the mobile telecommunication industry has intensified with the removal of obstacles to number portability among mobile service providers (GSM operators). Thus, the operators in the industry further increase their investments in loyalty programs and seek to effectively reach both current and potential customers by participating in social media tools which are intensely used by those customers. One of the social media tools mostly used by today's customers is Facebook. Firms can create contents that contain various messages and develop various applications (apps) via Facebook. The aim of this study is to investigate the applications developed by the firms of the mobile telecommunication industry via their Facebook pages and to test the effect of these applications on customer loyalty. In this regard, a survey based empirical research was conducted on the subscribers of GSM operators in Turkey who followed the official Facebook pages of these operators. The findings indicated that Facebook applications of mobile service providers had a significant influence on customer loyalty. The study also revealed that the most exploratory dimensions of Facebook applications were customer relations applications and informative applications.
\end{abstract}

Keywords: Turkey, Facebook applications, mobile telecommunication, customer loyalty

\section{Introduction}

Social media which emerged with Web 2.0 applications is a media system that enables multi-directional and simultaneous information sharing rather than one-way information sharing. It has begun to become one of the indispensables of today's consumers. This phenomenon directs the firms towards these channels and reveals the necessity of the firms to use the social media tools effectively.

Facebook is one of the social media tools that first come to mind regarding social media. It has more than 1 billion users and has become an inevitable channel for the firms that seek new customers or desire to make their current customers more loyal by strengthening their communication with them. Firms create and share various contents on their Facebook pages with various aims, such as introducing new products, advertising, being in constant contact with their customers and taking feedbacks from them. However, it is not as easy as presumed to affect customers on Facebook. Inexact applications that are to be developed on Facebook by the firms with no plan or aim may have negative effects both on the corporate identity of the firm and customer loyalty. Therefore, it is important for the firms to analyze the subjects such as moral values, expectations, preferences, and priorities of people who are the followers of these firms before they share anything on Facebook in order for the applications to be successful.

Due to the reasons such as a decline in the market growth rate, rapid increase in price competition, change in consumer preferences and needs in the mobile telecommunication industry, the firms in the industry continuously seek new strategies in order to survive in intense competition and to increase their profit rates per subscriber by diversifying their services (Barutçu, 2007). This is an industry in which competition is intense by nature and there is a need to use a great variety of marketing efforts and communication channels in order to reach the customers. Mobile service providers in the industry participate in social media channels such as Facebook and attempt to reach and appeal to their target customers by means of the applications they developed on these channels. 
Due to the results of the high usage of Facebook applications in the marketing efforts of GSM operators, the current study was conducted on the consumers of Turkish mobile telecommunication industry. Operators in the industry have approximately 7 million followers (Facebook, 2014). In this regard, the aim of this study is to investigate the Facebook applications of mobile service provider firms that operate in the Turkish mobile telecommunication industry and to test the effect of these applications on customer loyalty.

In this regard, the research questions we seek to answer as follows:

-To what extent do the dimensions that create Facebook applications of mobile telecommunication service providers represent their Facebook applications?

-What kind of effect do the Facebook applications of mobile telecommunication service providers have on customer loyalty?

The findings are expected to make a significant contribution to the relevant literature and will provide insights for the firms in the industry, GSM subscribers and shareholders.

\section{The Turkish Mobile Telecommunication Industry}

In Turkey, there are three mobile telecommunication operators: Turkcell, Vodafone Türkiye, and Avea. Turkcell operates under a 25-year GSM license, which it was granted in April 1998 upon payment of an upfront license fee of $\$ 500$ million. Telsim also received a 25 -year license with the $\$ 500$ million upfront license fee in 1998 . Telsim was then seized by the Savings Deposit Insurance Fund of Turkey (SDIF) in February 2004 and it was put up for sale by the SDIF in August, 2005. An auction was held for Telsim on December 2005 with Vodafone submitting the winning bid of $\$ 4.55$ billion. Two new GSM 1800 licenses were issued in 2000 and one of them were awarded to Is-Tim, a company which began offering GSM services in March 2001 under Aria brand name was formed by Telecom Italia Mobile and Isbank, one of the private banks in Turkey. Is-Tim paid a license fee of $\$ 2.5$ billion excluding taxes. The other GSM 1800 license was awarded to Türk Telekom. Türk Telekom began offering GSM services on December 2001, through its brand Aycell. In February 2004, Is-Tim and Aycell merged to form "TT\&TIM" which is owned by Turk Telekom, Telekom Italia Mobile and Isbank. TT\&TIM operated under the brand name of Avea (Turkcell, 2014).

The competition in the industry has further increased, especially with the number portability between the operators that became possible on November 9, 2008 (Güngör \& Evren, 2010). With the related regulation, a user that is not satisfied with the service provider has gained the opportunity to change it easily.

The general trends in the Turkish mobile telecommunication industry are shown in Table 1.

Table 1. Trends in the Turkish mobile telecommunication industry

\begin{tabular}{lccccc}
\hline Years & $\mathbf{2 0 0 9}$ & $\mathbf{2 0 1 0}$ & $\mathbf{2 0 1 1}$ & $\mathbf{2 0 1 2}$ & $\mathbf{2 0 1 3}$ \\
\hline Subcribes (Millions) & 63,6 & 61,7 & 63,9 & 66,7 & 68,6 \\
Population Penetration (\%) & 89 & 85,03 & 86,675 & 88,975 & 90,425 \\
\hline Subscriber Market Share of Operators (\%) & & & & & \\
\hline Avea & 19,2 & 18,70 & 19,29 & 19,73 & 20,49 \\
Turkcell & 56,62 & 54,93 & 53,23 & 52,30 & 50,89 \\
Vodafone Türkiye & 24,15 & 26,36 & 27,46 & 27,95 & 28,60 \\
\hline Mobile Average Revenue Per User (ARPU) (TL) & & & & & \\
\hline Avea & 16,725 & 18,575 & 20,35 & 21,575 & 22,275 \\
Turkcell & 18,5 & 19,3 & 19,7 & 20,9 & 21,825 \\
Vodafone Türkiye & 13,625 & 16,925 & 19,825 & 21.05 & 21,725 \\
Total Mobile Traffic (Billions Minutes) & 27,02 & 31,45 & 36,78 & 42.45 & 46,34 \\
\hline Net Sales (million TL) & \multicolumn{5}{c}{} \\
\hline Turkcell & 8.025 & 7.991 & 8.332 & 8.828 & 9.123 \\
Vodafone Türkiye & 2.584 & 3.349 & 3.741 & 4.380 & 5.734 \\
Avea & 2.406 & 2.497 & 2.906 & 3.354 & 3.838 \\
\hline
\end{tabular}

Source: Reconstructed from the webpages of ICTA (Information and Communication Technologies Authority) and Türk Telecom Group Investor Relations.

Accordingly, crucial increases were observed in the number of subscribers in the Turkish mobile telecommunication industry over the years. It is observed that there are approximately 69 million mobile users 
by the end of 2013 (Türk Telecom Group Investor Relations, 2014). According to Table 1, the penetration reached $90 \%$ in the industry. Among the firms in the industry, Avea comes first according to the revenue per user. According to net sales, Turkcell has an clear superiority in the industry. Furthermore, the total mobile traffic density shows an increase by years as well.

\section{Theoretical Background}

\subsection{A Brief Overview of Facebook}

Facebook, which is a social networking service launched in February 2004, was founded by Mark Zuckerberg with his college roommates in Harvard University. Within 24 hours, 1,200 Harvard students had signed up, and after one month, over half of the undergraduate population had a profile. Facebook was promptly extended to other universities and eventually all US universities. In August 2005, after the address was purchased for $\$ 200,000$, it became Facebook.com. US high schools could sign up from September 2005, then it began to spread worldwide (Philips, 2007)

Facebook became available to the general population aged over 13 years with a valid e-mail address in 2006 upon heavy demand and added characteristics, so that users can view information such as their friends' relationship status and employment status (Jenkins, 2013). Late in 2007, Facebook hosted more than 100,000 pages for businesses (Richmond, 2007). In 2008, it launched the "Chat" application that makes it possible for users to instant messaging each other and revised its design. In 2009, it included the "Like" feature, to which all users, especially brands, pay attention (Jenkins, 2013).

In 2010, Facebook provided the new profile design and the "Places" feature, which is a location application through which users can indicate their real time locations (Business\&Finance, 2014). In 2012, it purchased Instagram, an application that provides a service to share photographs (Jenkins, 2013). In 2014, for \$ 19 billion in total, it purchased WhatsApp, which provides a messaging service in order to complete its messaging service for some, and to stop the user loss of others (Binay, 2014). Facebook reached 1.23 billions of users by December 2013 (Facebook Investor Relations, 2014).

\subsection{The Reasons of Why Businesses Appear on Facebook}

It is not possible to reach customers through only one channel in the competitiveness of today. Therefore, businesses take advantage of using new communication tools like Facebook, in addition to the traditional ones. There are many reasons why businesses/brands seek to appear on Facebook. Some of them include (Lacho \& Marinello, 2010; Haataja, 2010; Frey \& Rudloff, 2010; Barnes, 2010):

-Allowing the introduction of goods and services to a very large market;

-Enabling the display of photographs and videos of products to followers or the customers;

-Making it possible to be in constant contact with customers via instant or daily sharings;

-Increasing the products' brand awareness with the increase in followers and likers;

-Providing mobile marketing through the connection between Facebook and mobile devices;

-Rapid, flexible, and effective way to reach big groups;

-Allowing new product development and change in current products by instant feedback and comments;

-Enabling personalization for the target group in promotions and advertisements;

-Less costly compared to the other communication tools;

-Allowing free advertisement through word of mouth by voluntary followers;

-Enabling brands to follow the status of their rivals;

-Making it possible for brands to follow customer trends and contact them personally;

-Making it easy to announce new products in the market;

-Providing benefits regarding productivity cost in the marketing efforts.

\subsection{Facebook Applications (Apps)}

Businesses develop various applications on Facebook in order to communicate with customers, learn their pleasures and preferences, or their brand perceptions and especially to turn them into loyal customers. These applications are, in general, classified under the titles of page applications, informative applications, customer relations applications, entertainment applications, and word of mouth communication applications. According to a relevant study (Kim \& Ko, 2010) conducted on luxurious brands, the social media efforts of the brands were 
determined as entertainment, customization, interaction, word of mouth communication, and trend.

\subsubsection{Page Applications}

By logging into their Facebook accounts every day, millions of users view the pages of businesses/brands they like and communicate with them. For a business or a brand to benefit from this publicity opportunity provided by Facebook, it first has to own a Facebook 'Like' page. This page can be formed easily and quickly. Like pages are the pages on which consumers, customers or employees, who enable the brands or businesses to appear institutionally on Facebook follow the business or brand.

In November 2007, these pages activated by Facebook proved to be an important tool for businesses in order to create brand awareness and existence on Facebook. These pages are free of charge and they make viral marketing available for both small and large scale firms (Akar, 2011). Businesses can share photographs about the brand, products, offers, detailed product information, and sponsorship projects, as well as viral videos, advertisement, or public relations videos. It would be beneficial if these contents shared on Facebook page are adjusted according to the followers' reaction to the sharing times in order to achieve the aim of the sharings and to reach many more users. Moreover, brands should remember special occasions and current events on Facebook (Hanson, 2012).

\subsubsection{Entertainment Applications}

Entertainment applications are developed for increasing the number of followers on Facebook pages and making them visit these pages again. These applications generally include games, contests, and sweepstakes that take place on the page. Through the games on Facebook pages, greater communication with the followers can be made and many more followers can be made accessible.

Moreover, these games, which are also called social gaming, provide important advantages for the brands to create an identity, to affect the purchasing decisions of the consumers, and to form customer loyalty (Eko, 2012). One of the applications used regarding the entertainment applications is the contests and the sweepstakes. Coca-Cola, Toys "R" Us, Silverline, GAP, and many more brands organize contests and sweepstakes. In order to organize a contest or sweepstake on Facebook, there is no need to request permission from Facebook or make any expenditures. To avoid any type of problems during the contest, it is necessary to obey the rules stated on Facebook Promotion Guidelines. It is considered that the followers find posts that contain entertaining content more favorable and adopt a positive attitude towards the brands that send those posts (Vries et al., 2012).

\subsubsection{Informative Applications}

Businesses can place any kind of information on the 'About' section of Facebook page such as basic information, contact details and the stages since their establishment. Businesses announce the offers, sales, sweepstakes, coupons, and contests they have made or they are going to make soon on their "Wall" so that their followers can view them.

It is considered that consumers have a more positive attitude towards informative advertisements on social media compared to the content and advertisements that do not contain any information (Vries et al., 2012).

\subsubsection{Customer Relations Applications}

The start of using social media tools such as Facebook in customer relations applications introduced the concept of the social CRM (customer relationship management). Social CRM is described as a business strategy that aims to create trust and loyalty in customers for the brand (Woodcock et al., 2011:52). Accordingly, social CRM is a business strategy that is designed to provide mutual benefit in communication with the customer in a safe and a transparent business environment, which is supported by a technological infrastructure, business rules, processes, and social qualities (Greenberg, 2009:8). In this respect, social CRM applications of the brands include applications that allow responses to questions asked and comments made over social media tools such as Facebook via this channel.

\subsubsection{Word of Mouth Communication Applications}

The evaluation of consumers about the brand, product or services being conducted through social media tools such as product analysis websites, consumer forums, manufacturer websites, brands' own websites, personal or brand blogs have created the concept of electronic word of mouth (e-wom) communication (Lee \& Youn, 2009).

Social media users are more open to receive and share word of mouth messages with other subscribers within the social groups they subscribed to. More than half of the social media users share their comments about the products they use. Additionally, social media users are closely interested in Facebook pages and profiles of the brands. Evaluations of brands and businesses may spread within the whole group in a short time, regardless of 
geographical borders. Two types of members within Facebook groups that generate the word of mouth communication and cause it to spread are the influencers and the connectors. Influencers are members from whom other members ask for information and they are generally seen as opinion leaders. Their ideas are in demand to be known by other members and they have crucial effects on other members. Connectors are group members who increase the spread of word of mouth communication by connecting group members with more connections (Cao et al., 2009, pp. 2).

\subsection{Social Media, Facebook and Customer Loyalty}

Customer loyalty has been one of the leading subjects for both academicians and practitioners. In the literature, there are much studies on customer loyalty including various industries such as telecommunication (Kim et al., 2001; Back \& Parks, 2003; Merisavo \& Raulas, 2004; Kim et al., 2004; Kim \& Yoon, 2004; Back, 2005; Lau et al., 2006; Consuegra et al., 2007; Yee \& Sidek, 2008; Obga \& Tan, 2009). Since loyalty contains a complex structure, there are different definitions used regarding the concept. Oliver (1999) provided one of the common definitions in the literature. Oliver (1999, p.34) described loyalty as "a deeply held commitment to repurchase or repatronize a preferred product/service consistently in the future, thereby causing repetitive same-brand or same brand-set purchasing, despite situational influences and marketing efforts having the potential to cause switching behavior".

According to the literature on loyalty, it is observed that there are three approaches developed for the measurement of loyalty. The first approach focuses on the behavioral aspects (McConnell, 1968). The second approach measures the loyalty with the attitudinal factors (Jacoby \& Keyner, 1973). The last approach considers the loyalty in a composite structure that has behavioral and attitudinal elements together (Dick \& Basu, 1994; Baloglu, 2002; Bennett \& Thiele, 2002). Accordingly, loyalty exists as a result of the interaction between a customer's relative attitude towards a special brand, and also their repeat purchase behaviour for that brand (Obga \& Tan, 2009, pp. 135). Therefore, loyalty is a function of both behavior and attitude and it reflects the consumer's preference for a particular brand within a product category in order to be purchased (Yee \& Sidek, 2008).

Since the social media is a relatively new concept, there are a limited number of studies regarding the effects of social media applications on loyalty. Kim \& Ko (2010), analyzed the influences of luxury fashion brand's social media marketing on customer relationships and purchase intention. As a result of their study, social media marketing properties such as entertainment, interaction and word of mouth communication had a positive impact on purchase intention.

Erdoğmuş \& Çiçek (2012), investigated the effect of social media marketing on consumers' customer loyalty. The results of the their study showed that advantageous campaigns on social media were the most significant drivers of customer loyalty followed by relevancy of the content, popularity of the content among friends, and appearing on different social media platforms and providing applications.

Laroche et al. (2013) examined how the effects of brand community translate to customer loyalty. According to their results, brand communities established on social media such as Facebook, My Space and Twitter had positive effects on brand trust, and trust had positive effects on customer loyalty.

In addition, it could be stated that interactive marketing communications such as Facebook have a distinct advantage in their ability to encourage learning, teaching, expression of commitment, and observation of customer loyalty amongst consumers (Bond, 2010:4).

Based on the above discussions, the research hypothesis is proposed as below:

H1: The Facebook applications of mobile telecommunication service providers will positively affect customer loyalty.

\section{Methodology}

\subsection{Purpose of the Study}

The main purpose of this study is to investigate the Facebook applications of mobile service providers operating in the Turkish mobile telecommunication industry and to test the impact of these applications on customer loyalty. The other aim of this study is to reveal to what extent these applications (page applications, entertainment applications, informative applications, customer relations applications and word of mouth communication applications) reflect the concept of Facebook applications.

\subsection{Sampling and Data Collection}

The population of this study includes all of the current users of GSM operators in Turkey who follow the official 
Facebook pages of these operators. Due to the certain restrictions such as time, cost and difficulty to reach all the population, the study was limited with the sample. Since there was no sample framework for the current users of these GSM operators, the convenience sampling method was used. Before the main study, through a convenience sampling approach, a pretest was conducted on 30 mobile phone users following the Facebook pages of these operators to assess whether the instrument could be clearly understood by participants. Some modifications were needed on the survey after the pretest. Then, some questions in the survey were revised and complemented. Data of the main study were collected through an online questionnaire using related webpage (https://docs.google.com). Over a two-month period (June-July 2013), the GSM subscribers were requested to participate in the study and the link of the online questionnaire was also forwarded to the Facebook pages of the relevant GSM Operators and the pages of different online groups which were related to the subject. A total of 750 users participated in online questionnaire.

\subsection{Measures}

The questionnaire form of the study consisted of two parts. The first part contained questions about the demographic characteristics of the participants. The second part included scales in order to measure the structures in the research model. The questions to measure the Facebook applications were drawn from the literature review (Safko \& Brake, 2009; Kim \& Ko, 2010; Kim \& Ko, 2011). Customer loyalty was adopted from the previous studies (Yoo \& Donthu, 2000; Halim, 2006; Lee et al., 2010). Participants were asked to rate the items using a five-point Likert type scales ( $1=$ Strongly disagree; $5=$ Strongly agree).

\subsection{Analysis Method}

Data were analyzed using structural equation modeling via AMOS.

\section{Results}

\subsection{Sample Profile}

Descriptive statistics showed that 54.8 percent of the respondents were male and 45.2 percent were female. Most of the participants ( 88 percent) were under 30 years old. 78.6 percent of the participants had graduate and postgraduate degrees. In particular, 36.1 percent bought mobile service from Turkcell, 32.4 percent from Avea, and 31.5 percent from Vodafone Türkiye.

\subsection{Measurement Model}

Anderson \& Gerbing's (1988) two-step approach was employed to evaluate the measurement and structural model. The measurement model was evaluated prior to the structural model. The confirmatory factor analysis (CFA) results regarding the structures in the measurement model were achieved by using maximum likelihood estimation. The structures in the measurement model are page applications, entertainment applications, informative applications, customer relations applications, word of mouth communication applications, and customer loyalty. Primarily, first-order confirmatory factor analyses were applied regarding these structures. As a next step, the representation power of the structures that form the Facebook applications was measured by employing the second-order confirmatory factor analysis.

The CFA results of the measurement model are indicated in Table 2.

Table 2. CFA results

\begin{tabular}{|c|c|c|}
\hline Scale/Items & $\begin{array}{c}\text { First-Order } \\
\text { Model } \\
\text { Factor } \\
\text { Loading } \\
\end{array}$ & $\begin{array}{c}\text { Second-Order } \\
\text { Model } \\
\text { Factor } \\
\text { Loading } \\
\end{array}$ \\
\hline \multicolumn{3}{|l|}{ Page Applications $\quad(\mathrm{C} . \mathrm{R} .=0.89, \mathrm{AVE}=0.63, \alpha=0.89)$} \\
\hline PA1- The Facebook page of my GSM Operator is neat. & 0.76 & 0.78 \\
\hline $\begin{array}{l}\text { PA2- Photographs about the brand (operator) and its services are shared on the Facebook page of } \\
\text { my GSM Operator. }\end{array}$ & 0.77 & 0.76 \\
\hline PA3- Comments can be made about sales and offers on the Facebook page of my GSM Operator. & 0.81 & 0.80 \\
\hline PA4-The Facebook page of my GSM Operator is updated continuously. & 0.84 & 0.83 \\
\hline $\begin{array}{l}\text { PA5-Videos about the brand (operator) and its services are shared on the Facebook page of my } \\
\text { GSM Operator. }\end{array}$ & 0.78 & 0.78 \\
\hline \multicolumn{3}{|l|}{ Entertainment Applications (C.R. $=0.87, \mathrm{AVE}=0.69, \alpha=0.86$ ) } \\
\hline EA1-Contests are organized on the Facebook page of my GSM Operator. & 0.80 & 0.83 \\
\hline
\end{tabular}




\begin{tabular}{|c|c|c|}
\hline EA2-Sweepstakes are organized on the Facebook page of my GSM Operator. & 0.94 & 0.90 \\
\hline EA3- Games are played on the Facebook page of my GSM Operator. & 0.73 & 0.75 \\
\hline \multicolumn{3}{|l|}{ Informative Applications $(\mathrm{C} . \mathrm{R} .=0.89, \mathrm{AVE}=0.68, \alpha=0.89$ ) } \\
\hline $\begin{array}{l}\text { IA1-Information about the brand (operator) is shared on the Facebook page of my GSM } \\
\text { Operator. }\end{array}$ & 0.79 & 0.80 \\
\hline IA2-Sales/promotions/offers news are shared on the Facebook page of my GSM Operator. & 0.86 & 0.85 \\
\hline IA3-Brand/firm events are shared on the Facebook page of my GSM Operator. & 0.86 & 0.85 \\
\hline IA4-Sponsorship activities are shared on the Facebook page of my GSM Operator. & 0.78 & 0.80 \\
\hline \multicolumn{3}{|l|}{ Customer Relations Applications (C.R. $=0.88, \mathrm{AVE}=0.60, \alpha=0.88$ ) } \\
\hline CRA1- An online support is provided on the Facebook page of my GSM Operator. & 0.79 & 0.77 \\
\hline $\begin{array}{l}\text { CRA2- Online question and answer application is provided on the Facebook page of my GSM } \\
\text { Operator. }\end{array}$ & 0.84 & 0.81 \\
\hline $\begin{array}{l}\text { CRA3- During the process of campaign creation, my GSM Operator obtains the opinions of the } \\
\text { subscribers via Facebook page. }\end{array}$ & 0.79 & 0.79 \\
\hline CRA4-Special days and occasions are remembered on the Facebook page of my GSM Operator. & 0.68 & 0.72 \\
\hline CRA5-My GSM Operator communicates with its subscribers over Facebook. & 0.78 & 0.80 \\
\hline \multicolumn{3}{|l|}{ Word of Mouth Communication Applications (C.R. $=0.89, \mathrm{AVE}=0.74, \alpha=0.89$ ) } \\
\hline $\begin{array}{l}\text { WMA1-I share the information about the brand (operator) on my 'Wall' that are shared on the } \\
\text { Facebook page of my GSM Operator. }\end{array}$ & 0.88 & 0.77 \\
\hline $\begin{array}{l}\text { WMA2-It is possible to share information with other subscribers through the Facebook page of } \\
\text { my GSM Operator. }\end{array}$ & 0.89 & 0.79 \\
\hline $\begin{array}{l}\text { WMA3-I share the videos and photographs on my page that are shared on the Facebook page of } \\
\text { my GSM Operator. }\end{array}$ & 0.81 & 0.65 \\
\hline
\end{tabular}

\begin{tabular}{|c|c|c|c|}
\hline \multicolumn{4}{|c|}{ Structural Parameters of the Second Order Model } \\
\hline Facebook Applications & Page Applications & \multicolumn{2}{|c|}{0.82} \\
\hline Facebook Applications & Entertainment Applications & \multicolumn{2}{|c|}{0.78} \\
\hline Facebook Applications & Informative Applications & \multicolumn{2}{|c|}{0.88} \\
\hline Facebook Applications & Customer Relations Applications & \multicolumn{2}{|c|}{0.93} \\
\hline Facebook Applications & Word of Mouth Communication Applications & \multicolumn{2}{|c|}{0.74} \\
\hline \multirow[t]{8}{*}{ Model Fit Statistics } & & $\left(\chi^{2}\right)=790.165$ & $(\chi 2)=939.041$ \\
\hline & & $\mathrm{df}=159$ & $\mathrm{df}=164$ \\
\hline & & $\chi^{2 / \mathrm{df}}=4.97$ & $\chi 2 / \mathrm{df}=5.73$ \\
\hline & & $\mathrm{GFI}=0.91$ & $\mathrm{GFI}=0.87$ \\
\hline & & $\mathrm{AGFI}=0.88$ & AGFI $=0.85$ \\
\hline & & $\mathrm{TLI}=0.93$ & $\mathrm{TLI}=0.92$ \\
\hline & & $\mathrm{CFI}=0.94$ & $\mathrm{CFI}=0.93$ \\
\hline & & RMSEA $=0.073$ & RMSEA $=0.079$ \\
\hline
\end{tabular}

Customer loyalty $(\mathrm{C} . \mathrm{R} .=0.91, \mathrm{AVE}=0.73, \alpha=0.90)$

BL1 - I consider myself to be loyal to this GSM operator.

BL2- This GSM operator would be my first choice.

BL3-I will continue to buy this GSM operator even though there are other operators.

BL4-Even if the price is more expensive, I would still buy this GSM operator.

Model Fit Statistics

$\begin{array}{ll}0.89 & 0.80 \\ 0.97 & 0.94 \\ 0.89 & 0.80 \\ 0.60 & 0.36\end{array}$

$$
\begin{gathered}
(\chi 2)=2.63 \\
\mathrm{df}=1 \\
\chi 2 / \mathrm{df}=2.63 \\
\mathrm{GFI}=0.99 \\
\mathrm{AGFI}=0.98 \\
\mathrm{TLI}=0.99 \\
\mathrm{CFI}=0.99 \\
\text { RMSEA }=0.047
\end{gathered}
$$

As presented in Table 2, factor loadings ranged from 0.76 to 0.84 for page applications, from 0.73 to 0.94 for entertainment applications, from 0.78 to 0.86 for informative applications, from 0.68 to 0.84 for customer relations applications, and from 0.81 to 0.89 for word of mouth communication applications. The model fit statistics showed that the measurement model yielded an adequate fit $((\chi 2)=790.165, \mathrm{df}=159, \chi 2 / \mathrm{df}=$ 
$4.97, \mathrm{GFI}=0.91, \mathrm{AGFI}=0.88, \mathrm{TLI}=0.93, \mathrm{CFI}=0.94, \mathrm{RMSEA}=0.073)$. Another variable in the measurement model is customer loyalty, which is an endogenous variable. Factor loadings of customer loyalty ranged from 0.60 to 0.89 . The fit statistics of customer loyalty provided good fit $\left(\left(\chi^{2}\right)=2.63 ; \mathrm{df}=1 ; \chi 2 / \mathrm{df}=2.63 ; \mathrm{GFI}=\right.$ $0.99 ; \mathrm{AGFI}=0.98 ; \mathrm{TLI}=0.99 ; \mathrm{CFI}=0.99 ; \mathrm{RMSEA}=0.047$ ).

To what extent the structures that form the Facebook applications represent the Facebook applications was revealed by performing the second order confirmatory factor analysis. According to Table 2, Facebook applications with the highest explanatory estimates were customer relations applications (0.93) and informative applications (0.88). Thus, it can be suggested that customer relations and informative applications were the most reliable indicators of Facebook applications.

Composite reliability and AVE coefficients of each construct in the measurement model were calculated. As shown in Table 3, all constructs had desirable levels of composite reliability (ranging from 0.87 to 0.91 ) and AVE coefficients (ranging from 0.60 to 0.74 ). Since the factor loadings $(>.60)$ of the constructs in the model and reliability values were above the recommended levels, the convergent validity was upheld.

As for discriminant validity, it was assessed by considering the AVE values. Discriminant validity can be ensured while the AVE values are generally greater than the squared correlations between the variables in the model (Fornell \& Larcker, 1981). As shown in Table 3, the AVE values were generally greater than the squared correlations, providing the discriminant validity.

Table 3. Measure correlations, the squared correlations, AVE and CR

\begin{tabular}{|c|c|c|c|c|c|c|c|c|}
\hline Constructs & Page Apps & $\begin{array}{l}\text { Entertainm } \\
\text { ent Apps }\end{array}$ & $\begin{array}{l}\text { Informative } \\
\text { Apps }\end{array}$ & $\begin{array}{l}\text { Customer } \\
\text { Relations } \\
\text { Apps }\end{array}$ & $\begin{array}{l}\text { Word of } \\
\text { Mouth } \\
\text { Com.Apps }\end{array}$ & $\begin{array}{l}\text { Customer } \\
\text { loyalty }\end{array}$ & AVE & $\begin{array}{l}\text { Composite } \\
\text { Reliability } \\
(\mathrm{CR})\end{array}$ \\
\hline 1)- Page Apps & 1.00 & & & & & & 0.63 & 0.89 \\
\hline 2)- Entertainment Apps & $0.61(0.37)$ & 1.00 & & & & & 0.69 & 0.87 \\
\hline 3)- Informative Apps & $0.84(0.71)$ & $0.67(0.45)$ & 1.00 & & & & 0.68 & 0.89 \\
\hline $\begin{array}{l}\text { 4)- Customer Relations } \\
\text { Apps }\end{array}$ & $0.72(0.52)$ & $0.74(0.55)$ & $0.79(0.62)$ & 1.00 & & & 0.60 & 0.88 \\
\hline $\begin{array}{l}\text { 5)- Word of Mouth Com. } \\
\text { Apps }\end{array}$ & $0.52(0.27)$ & $0.61(0.37)$ & $0.58(0.34)$ & $0.78(0.61)$ & 1.00 & & 0.74 & 0.89 \\
\hline 6)- Customer loyalty & $0.54(0.29)$ & $0.40(0.16)$ & $0.58(0.34)$ & $0.49(0.24)$ & $0.35(0.12)$ & 1.00 & 0.73 & 0.91 \\
\hline
\end{tabular}

According to Table 3, correlation values between the constructs in the model ranged from 0.35 and 0.84 .

\subsection{Structural Model and Hypothesis Testing}

The structural analysis was executed using maxium likelihood estimation. The structural model is shown in Figure 1. Overall, the structural model yielded an adequate fit $(\chi 2=1200.092 ; \mathrm{df}=244 ; \chi 2 / \mathrm{df}=4.92$; $\mathrm{GFI}=0.87 ; \mathrm{AGFI}=0.85 ; \mathrm{TLI}=0.92 ; \mathrm{CFI}=0.93 ; \mathrm{RMSEA}=0.072$ ). 


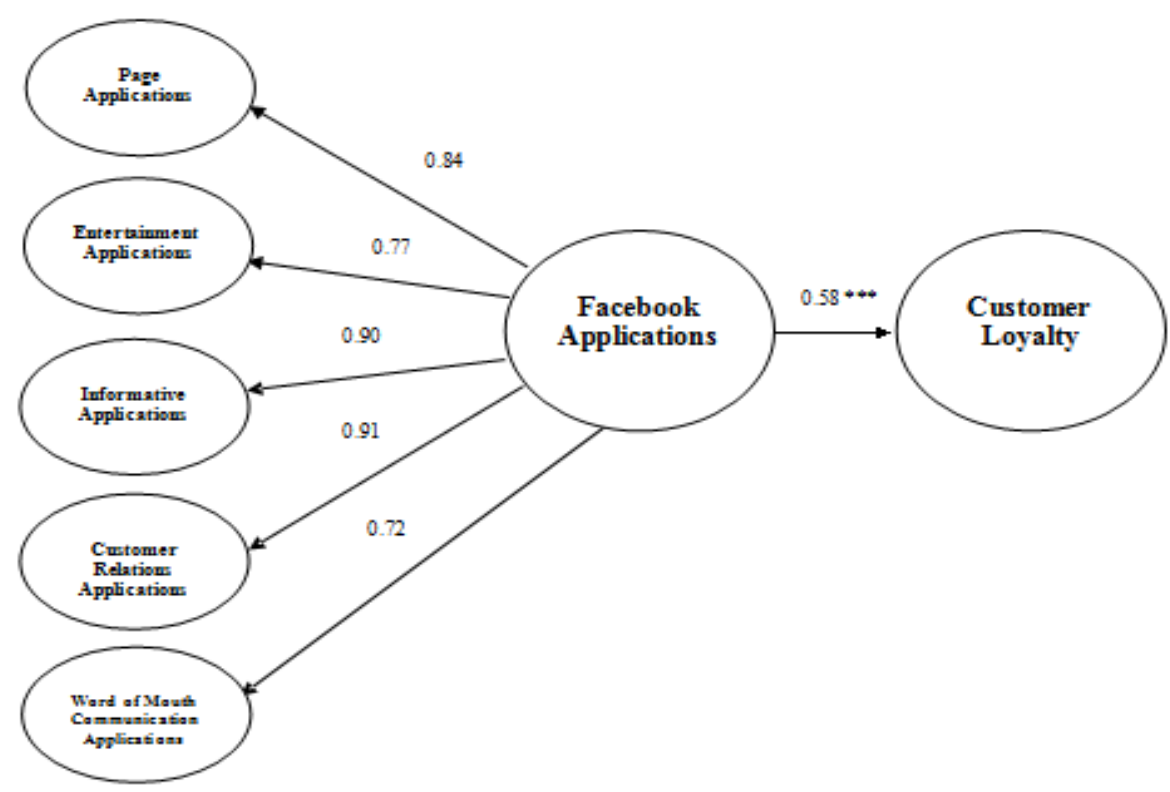

Figure 1. Structural model

Note. $* * * \mathrm{p}<.001$.

The result of hypothesis testing is indicated in Table 4.

Table 4. Structural parameter estimate

\begin{tabular}{|c|c|c|c|c|}
\hline Hypothesized Path & Coefficent & t-Value & Sig. & Result \\
\hline $\begin{array}{l}\text { H1: Facebook Applications } \longrightarrow \text { Customer Loyalty } \\
\text { Squared Multiple Correlations for Customer Loyalty }=0.34\end{array}$ & 0.58 & 15.689 & $* * *$ & Supported \\
\hline
\end{tabular}

According to Table 4, Facebook applications showed a significant impact on customer loyalty $(\beta=0.58 ; \mathrm{t}=$ 15.689; $\mathrm{p}<0.001$ ), supporting H1. Besides, the degree of variance explained by Facebook applications for customer loyalty was 0.34 .

\section{Conclusions and Implications}

The study presented here tested the relationship between the Facebook applications of mobile service providers that operate in the Turkish mobile communication industry and customer loyalty. Primarily, Facebook applications of mobile service providers were examined. Upon this study, a battery was established in order to measure the Facebook applications with the variables acquired from the scales used in the related literature. Facebook applications consist of five dimensions, which are page applications, entertainment applications, informative applications, customer relations applications, and word of mouth communication applications. As a consequence of the validity and reliability analyses, it can be stated that this battery related to Facebook applications may be suggested. Because, an acceptable fit was provided between data and model for the Facebook applications measurement model.

To what extent the dimensions of Facebook applications represent the Facebook applications was revealed as a result of the second-order confirmatory factor analysis. Accordingly, the most reliable indicators of Facebook applications were customer relations applications and informative applications. This was followed by page, entertainment, and word of mouth communication applications, respectively.

Mobile service providers communicate with their customers through these applications over their Facebook pages and try to influence their brand perceptions. The structural analysis revealed that the Facebook applications positively affected the customer loyalty (coefficient: 0.58). Moreover, informative applications were the Facebook applications that had the highest correlation with customer loyalty (coefficient: 0.58 ). It was also revealed that the strongest correlation among the Facebook applications was between informative 
applications and page applications (coefficient: 0.84 ).

The study findings provides various implications for businesses. It has become obligatory for today's businesses to have a Facebook page, since there is a great interest in social media. Businesses with Facebook pages can provide information over this page for their followers on the subjects such as business details, products, offers, and sponsorships. The primary application that brands should always include on their Facebook pages is the entertainment application. As part of the entertainment applications, the necessity for the brands to include contests, sweepstakes, and games on their pages arises. Considering the customer relations applications, it can be stated that it is very important for businesses to answer the questions asked through Facebook accurately and quickly, and to provide technical support over Facebook when necessary

Considering informative applications, the use of visual elements by businesses to provide information about the subjects such as institutional structures, customer perceptiveness, and contact details in first place, special offers, sales and events may positively affect customers attitudes. The other crucial issue businesses/brands should take into account on their Facebook pages is paying special attention to applications that would initiate or accelerate the word of mouth communication. In this regard, businesses should conduct efforts to surprise the followers, make them share on their walls, and mention such efforts to their friends.

In sum, the applications made via Facebook pages by the firms that are active in the mobile telecommunication market increase customer loyalty. These firms should continue creating awareness in their efforts in order to strengthen their customer loyalty.

\section{Limitations and Future Research}

There are some limitations to the generalizability of the findings of this study. This study is limited to individuals that participated in this research and follow the Facebook pages of the three mobile service providers which operate in Turkey. Thus, it is quite difficult to generalize the study findings. Besides, since the data were obtained by an online questionnaire and only willing individuals participated in it, the reliability of the answers may be questionable. Moreover, because the data were collected at once, changing customer perceptions towards Facebook applications were also ignored.

Comparative researches among firms that operate in the mobile telecommunication industry may be conducted in the future studies. Therefore, it can be determined to what extent which Facebook application is effective for which mobile service provider. In the current study, the role of Facebook applications on customer loyalty was examined. In further studies, the effects of other social media tools on loyalty can be analyzed. Additionally, more comprehensive models can be tested with other variables that are the antecedents of customer loyalty in order to examine the relative effect of Facebook applications on these variables. Furthermore, future reseach should address to what extent Facebook applications are applicable regarding different sectors.

\section{References}

Anderson, J. C., \& Gerbing, D. W. (1988). Structural Equation Modeling in Practice: A Review and Recommended Two Step Approach. Psychological Bulletin, 103(3), 411-423. http://dx.doi.org/10.1037/0033-2909.103.3.411

Akar, E. (2011). Sosyal Medya Pazarlaması: Sosyal Webde Pazarlama Stratejileri. Elif Yayınevi, Ankara

Back, K. J., \& Parks, S. C. (2003). A Customer loyalty Model Involving Cognitive, Affective, and Conative Brand Loyalty and Customer Satisfaction. Journal of Hospitality \& Tourism Research, 27(4), 419-435.

Back, K. J. (2005). The Effects of Image Congruence on Customers' Brand Loyalty in the Upper Middle-Class Hotel Industry, Journal of Hospitality \& Tourism Research, 29(4), 448-467. http://dx.doi.org/10.1177/1096348005276497

Baloglu, S. (2002). Dimensions of Customer Loyalty: Separating Friends from Well Wishers. Cornell Hotel and Restaurant Administration Quarterly, 43, 47-59. http://dx.doi.org/10.1016/S0010-8804(02)80008-8

Barnes, N. G. (2010). How Do the Most Successful Companies Use Social Media? Marketing Research, Spring, $8-10$.

Barutçu, S. (2007). GSM Sektöründe Müşteri Bağlılığı: Pamukkale Üniversitesi Öğrencilerinin GSM Operatörlerine Bağl1lıkları ve Bağll1kklarını Etkileyen Faktörler. Afyon Kocatepe Üniversitesi, I.I.I.B.F Dergisi, 6, S.1

Bennett, R., \& Thiele, S. R. (2002). A Comparison of Attitudinal Loyalty Measurement Approaches. Journal of Brand Management, 9(3), 193-209. 
Binay, O. (2014). Facebook WhatsApp'1 neden satın aldı Rerieved from http://www.milliyet.com.tr/facebook-whatsapp-i-nedensatin/gundem/detay/1840510/default.htm

Bond, C. (2010). Engagement with Social Media and Outcomes for Brands: A Conceptual Framework. ANZMAC 2010. Retrieved from http://anzmac2010.org/proceedings/pdf/anzmac10Final00478.pdf

Business \& Finance. (2014). Infographic: Facebook in Numbers. Retrieved from $\mathrm{http} / /$ businessandfinance.com/infographic-facebook-in-numbers/?ref

Cao, J., Knotts, T., Xu, J., \& Chau, M. (2009). Word of Mouth Marketing through Online Social Networks. Proceedings of the Fifteenth Americas Conference on Information Systems. San Francisco, California: Americas Conference on Information Systems.

Consuegra, D. M., Molina, A., \& Esteban, A. (2007). An Integrated Model Of Price, Satisfaction and Loyalty: An Empirical Analysis in the Service Sector. Journal of Product \& Brand Management, 16(7), 459-468 http://dx.doi.org/10.1108/10610420710834913

Dick, A. S., \& Basu, K. (1994). Customer Loyalty: Toward An Integrated Conceptual Framework, Journal of the Academy of Marketing Science, 22(2), 99-113. http://dx.doi.org/10.1177/0092070394222001

Eko, S. (2012). 4 Ways Brands Use Social Games on Facebook. Retrieved from http://ibrandstudio.com/articles/facebook-social-games-power-brands

Erdoğmuş, İ. E., \& Çiçek, M. (2012). The Impact of Social Media Marketing on Brand Loyalty. 8th International Strategic Management Conference. Procedia-Social and Behavioral Sciences, 58, 1353-1360

Facebook. (2014). Retrieved from https://www.facebook.com/vodafoneTR?fref=ts

Facebook Investor Relations. (2014). Facebook Reports Fourth Quarter and Full Year 2013 Results. Retrieved from http://investor.fb.com/releasedetail.cfm?ReleaseID $=821954$

Fornell, C., \& Larcker, D. F. (1981). Evaluating Structural Equation Models with Unobservable Variables and Measurement Error. Journal of Marketing Research, 18(1), 39-50. http://dx.doi.org/10.2307/3151312

Frey, B., \& Rudloff, S. (2010). Social media and impact on markating communication. Lulea University, Department of Business Adminisration and Social Sciences. Unpublished Graduation Thesis.

Greenberg, P. (2009). Social Crm Comes of Age. Retrieved from http://www.oracle.com/us/products/applications/crmdemand/036062.pdf

Güngör M., \& Evren, G. (2010). Mobil Numara Taşınabilirliği. Rekabete ve Tüketicilere Etkileri: Ardıl Düzenleyici Etki Analizi Çalı̧̧ması. Sektörel Araştırma ve Stratejiler Dairesi Başkanlığı, Bilgi Teknolojileri ve İletişim Kurumu. Retrieved from http://www.nts.gov.tr/files/DEA_MNT_v4.pdf

Haataja, M. (2010). Social Media Applications In Marketing Communications Of The Marketing Oriented Companies. Department of Marketing and Management, Aalto University School of Economics. Unpublished Master Thesis.

Halim, R. E. (2006). The Effect of the Relationship of Brand Trust and Brand Affect on Brand Performance: An Analysis from Brand Loyalty Perspective-A Case of Coffee Instant Product in Indonesia. Retrieved from http://ssrn.com/abstract $=925169$

Hanson, A. (2012). 6 Types of pictures Brands Share on Facebook. Retrieved from http://prdaily.com/Main/Articles/6_types_of_pictures_brands_share_on_Facebook_12707.aspx

ICTA. (2014). Information and Communication Technologies Authority, Electronic Communications Market in Turkey. Retrieved from http://eng.btk.gov.tr/kutuphane_ve_veribankasi/pazar_verileri/2013_Q4_ECM_MarketData.pdf

Jacoby, J., \& Kyner, D. B. (1973). Brand Loyalty vs. Repeat Purchasing Behavior. Journal of Marketing Research, 10(1), 1-9. http://dx.doi.org/10.2307/3149402

Jenkins, B. (2013). Keeping up With Zuck: A Brief History of Facebook Features. Techniques: Connecting Education \& Careers, 88(8), 60.

Kim, C. K., Han, D., \& Park, S. B. (2001). The Effect of Brand Personality and Brand Identification on Brand Loyalty: Applying the Theory of Social Identification. Japanese Psychological Research, 43(4), 195-206.

Kim, M. K., Park, M. C., \& Jeong, D. H. (2004). The Effects of Customer Satisfaction and Switching Barrier on Customer Loyalty in Korean Mobile Telecommunication Services. Telecommunications Policy, 28, 
145-159. http://dx.doi.org/10.1016/j.telpol.2003.12.003

Kim, H. S., \& Yoon, C. H. (2004). Determinants Of Subscriber Churn and Customer Loyalty in the Korean Mobile Telephony Market. Telecommunications Policy, 28, 751-765 http://dx.doi.org/10.1016/j.telpol.2004.05.013

Kim, A. J., \& Ko, E. (2010). Impacts of Luxury Fashion Brand's Social Media Marketing on Customer Relationship and Purchase Intention. Journal of Global Fashion Marketing, 164-171. http://dx.doi.org/10.1080/20932685.2010.10593068

Kim, A. J., \& Ko, E. (2011). Do social media marketing activities enhance customer equity? An empirical study of luxury fashion brand. Journal of Business Research, 65, 1480-1486. http://dx.doi.org/10.1016/j.jbusres.2011.10.014

Lacho, K. J., \& Marinello, C. (2010). How Small Business Owners Can Use Social Networking to Promote Their Business. The Entrepreneurial Executive, 15.

Laroche, M., Habibi, M. R., \& Richard, M. O. (2013). To Be or Not to Be in Social Media: How Brand Loyalty is Affected by Social Media? International Journal of Information Management, 33, 76-82. http://dx.doi.org/10.1016/j.ijinfomgt.2012.07.003

Lau, M. M., Chang, M. T., Moon, K. L., \& Liu, W. S. (2006). The Brand Loyalty of Sportswear in Hong Kong”, Journal of Textile and Apparel, Technology and Management, 5(1), 1-13.

Lee, M., \& Youn, S. (2009). Electronic word of mouth (eWOM). International Journal of Advertising, 28(3), 473-499. http://dx.doi.org/10.2501/S0265048709200709

Lee, S., Shin, H., Park, J. J., \& Kwon, O. R. (2010). A Brand Loyalty Model Utilitizing Team Identification and Customer Satisfaction in the Licensed Sports Product Industry. Journal of Research, 5(1), 60-67.

Mcconnell, J. D. (1968), The Development of Brand Loyalty: An Experimental Study. Journal of Marketing Research, 5(1), 13-19. http://dx.doi.org/10.2307/3149788

Merisavo, M., \& Raulas, M. (2004). The Impact of e-mail Marketing on Brand Loyalty. Journal of Product \& Brand Management, 13(7), 498-505. http://dx.doi.org/10.1108/10610420410568435

Obga, I. E., \& Tan, Z. (2009). Exploring the Impact of Brand Image on Customer Loyalty and Commitment in China. Journal of Technology Management in China, 4(2), 132-144. http://dx.doi.org/10.1108/17468770910964993

Oliver, R. L. (1999). Whence Consumer Loyalty? Journal of Marketing, 63, 33-44 http://dx.doi.org/10.2307/1252099

Philips, S. (2007). A Brief History of Facebook. Retrieved from http://www.theguardian.com/technology/2007/jul/25/media.newmedia

Richmond, R. (2007). Facebook-a Marketer's Friend-Site Offer Platform to Tout Product, Interact with Users. Retrieved from http://online.wsj.com/news/articles/SB119612078598804556

Safko, L., \& Brake, D. K. (2009). The Social Media Bible: Tactics, Tools, Strategies for Business Success. United States, Hoboken: New Jersey, John Wiley \& Sons, Inc.

$\begin{array}{lllll}\text { Turkcell. (2014). Market Information. } & \text { Retrieved }\end{array}$ http://www.turkcell.com.tr/en/aboutus/investor-relations/market-information

Türk Telecom Group Investor Relations. (2014). Turkish Information and Communication Technologies Authority. Retrieved from http://www.ttinvestorrelations.com/_files/xls/en/2013/Turkish-ICTA-Market-Data-Q4-2013.xlsx

Vries, L. D., Gensler, S., \& Leflang, P. S. H. (2012). Popularity of Brand Posts on Brand Fan Pages: An Investigation of the Effects of Social Media Marketing. Journal of Interactive Marketing, 26, 83-91. http://dx.doi.org/10.1016/j.intmar.2012.01.003

Woodcock, N., Green, A., \& Starkey, M. (2011). Social CRM as a business strategy. Journal of Database Marketing \& Customer Strategy Management, 18, 50-64. http://dx.doi.org/10.1057/dbm.2011.7

Yee, W. F \& Sidek, Y. (2008), Influence of Brand Loyalty on Consumer Sportswear. International Journal of Economics and Management, 2(2), 221-236.

Yoo, B., Donthu , N., \& Lee, S. (2000). An Examination of Selected Marketing Mix Elements and Brand Equity, 
Journal of the Academy of Marketing Science, 28(2), $195-211$. http://dx.doi.org/10.1177/0092070300282002

\section{Copyrights}

Copyright for this article is retained by the author(s), with first publication rights granted to the journal.

This is an open-access article distributed under the terms and conditions of the Creative Commons Attribution license (http://creativecommons.org/licenses/by/3.0/). 